Retraction

\title{
Retracted: The Role of Tomographic Ultrasonography in Conduit Mapping before Coronary Artery Bypass Grafting
}

\author{
Radiology Research and Practice
}

Received 10 September 2020; Accepted 10 September 2020; Published 25 November 2020

Copyright (c) 2020 Radiology Research and Practice. This is an open access article distributed under the Creative Commons Attribution License, which permits unrestricted use, distribution, and reproduction in any medium, provided the original work is properly cited.

Radiology Research and Practice has retracted the article titled "The Role of Tomographic Ultrasonography in Conduit Mapping before Coronary Artery Bypass Grafting" [1]. An investigation completed by the University of Manchester concluded that the author of the article did not possess the appropriate permissions for the publication of the data. It is therefore being retracted with the agreement of the journal and the University of Manchester. The author, Syed Mohammad Asim Hussain, does not agree to the retraction.

\section{References}

[1] S. M. A. Hussain, "The Role of Tomographic Ultrasonography in Conduit Mapping before Coronary Artery Bypass Grafting," Radiology Research and Practice, vol. 2018, Article ID 2097305, 7 pages, 2018. 